\title{
Inhibition of Xanthine Oxidase Activity by Ethanolic Extract of Peperomia pellucida L., Acacypha indica L. and Momordica charantia L.
}

\author{
Parawansah $^{1, *}$, Nuralifah ${ }^{2}$, Gemini Alam³ ${ }^{3}$ Rosdiana Natzir ${ }^{4}$ \\ ${ }^{1}$ Department of Pharmacology, Faculty of Medicine, Halu Oleo University, Kampus Hijau Bumi Tridharma, J1. H.E.A. Mokodompit, Kendari, Indonesia \\ ${ }^{2}$ Department of Pharmacology, Faculty of Pharmacy, Halu Oleo University, Kampus Hijau Bumi Tridharma, Jl. H.E.A. Mokodompit, Kendari, Indonesia \\ ${ }^{3}$ Faculty of Pharmacy, Hasanuddin University, Jl. Perintis Kemerdekaan Km.10, Makassar, Indonesia \\ ${ }^{4}$ Department of Biochemistry, Faculty of Medicine Hasanuddin University, J1. Perintis Kemerdekaan Km.10, Makassar, Indonesia \\ *Corresponding author. E-mail: parawansah_biom@yahoo.co.id
}

Received date: Mar 3, 2016; Revised date: Jul 27, 2016; Accepted date: Aug 8, 2016

\section{Abstract}

$\mathrm{B}$ ACKGROUND: Uric acid is a final result of purine catabolism, the enzymatic reactions in the body cells from amino acids or ribonucleotide dinucleotide. Peperomia pellucida L. (P. pellucida), Acalypha indica L. (A. indica) and Momordica charantia L. (M. charantia) are plants which have efficacy to reduce levels of uric acid excess. The aim of this research is to find out the effect of ethanol extract of $P$. pellucida, A. indica and M. charantia in preventing the formation of uric acid excess by inhibiting the action of the enzyme xanthine oxidase and comparing the inhibition activity of xanthine oxidase on treatments.

METHODS: The study design is experimental and conducted using the enzyme xanthine oxidase, xanthine (substrate), pH 7.5 phosphate buffer, samples (P. pellucida, A. indica and M. charantia ethanol extracts) and HCL as reaction breaker. Inhibition of xanthine oxidase was determined enzymatically and unreacted xanthine was measured by UV spectrophotometer at $290 \mathrm{~nm}$. The data were expressed as percent inhibition and the inhibitory concentration (IC) $)_{50}$ were determined using linear regresion of inhibition activity $v s$. concentration.

RESULTS: The $\mathrm{IC}_{50}$ of P. pellucida, A. indica and $M$. charantia ethanol extracts in inhibiting xanthine oxidase were $19.5 \mathrm{ppm}, 77.6 \mathrm{ppm}$ and $17.8 \mathrm{ppm}$, respectively. $\mathrm{IC}_{50}$ of allopurinol was $1.99 \mu \mathrm{g} / \mathrm{mL}$, and negative control (combination of enzyme and substrate) has absorbance value of 0.75026 .

CONCLUSION: Ethanol extract of $M$. charantia showed the most potent inhibition toward xanthine oxidase compared to the other two extracts.

KEYWORDS: xanthine oxidase, Peperomia pellucida L., Acalypha indica L., Momordica charantia L.

Indones Biomed J. 2016; 8(3): 161-6

\section{Introduction}

Uric acid is a final result of catabolism purines, the enzymatic reactions in the body cells from amino acids or ribonucleotide dinucleotide.(1,2) The occurence of hyperuricemia, or excessive increase of uric acid in the blood, will cause gout disease. $(3,4)$ Xanthine catalyzed by the enzyme xanthine oxidase will form uric acid. Xanthine oxidase, which plays an important role in the purines catabolism, is found in liver and muscle cells, but can not 
be found in the blood.(5) The normal value of uric acid level is 3.5 to $7.0 \mathrm{mg} / \mathrm{dL}$ for man and 2.5 to $6.0 \mathrm{mg} / \mathrm{dL}$ for women.

The intake of foods containing high purines will increase uric acid levels. The use of Peperomia pellucida L. (P. pellucida), Acalypha indica L. (A. indica) and Momordica charantia L. (M. charantia) in lowering uric acid levels is very beneficial. Purine and pyrimidine nucleotides synthesized in vivo at a pace that is consistent with physiological needs. The purine bases are then oxidized to uric acid, which may be absorbed and excreted in the urine. While little or no dietary purine or pyrimidine is incorporated into tissue nucleic acids. There are three processes that have roles in the biosynthesis of purine nucleotides. These three processes, sorted from the most important, are the synthesis of intermediates amphibolic (synthesis de novo), phosphorylation of purine and phosphorylation of purine nucleoside.

Adenosine first undergoes deamination into inosine by the help of adenosine deaminase enzyme.(6) Hypoxanthine and xanthine guanine subsequently formed in a reaction catalyzed by enzyme xanthine oxidase and guanase, respectively. The oxidized xanthine is turned into uric acid in the second reaction catalyzed by the enzyme xanthine oxidase. Thus, xanthine oxidase is an essential place for pharmacological intervention in patients with hyperuricemia and gout. $(7,8)$

These days, many number of plants have been proved empirically or by scientific testing and used as alternative treatments.(9) Some plants have been proved to be effective in lowering the level of uric acid excess, those are P. pellucida, A. indica and M. charantia.

Other efficacy of P.pellucida is its ability to cope with headache, abdominal pain, abscesses, ulcers, kidney disorders, acne, dermatitis, minor burns and pain in rheumatoid arthritis.(10,11) Extract of P. pellucida 1g/ $\mathrm{kg}$ bw/day in rats induced potassium oxonate three hours before treatment, suggesting that P. pellucida can be used as an alternative medicine for uric acid.(12)

Beside it effects as an anti-uric acid, $A$. indica also has efficacy as an anti-inflammatory, diuretic, laxative and hemostasis. Extract of $A$. indica $2.7 \mathrm{~g} / 200 \mathrm{~g}$ bw/day can effectively lower uric acid level in rats, which induced potassium oxonate one hour before treatment.(13)

Another plant that is often used in the treatment of uric acid is M. charantia.(14) Therefore, this study was done to find out the in vitro effects of P. pellucida, A. indica and $M$. charantia ethanol extract in inhibiting uric acid formation

\section{Methods}

An experimental study with post-test group design was conducted in three treatment groups with three times repetition. For blanks solution, $2.8 \mathrm{~mL}$ potassium phosphate buffer $\mathrm{pH} 7.5$ was inserted then $0.1 \mathrm{~mL}$ xanthine was added. Potassium phosphate buffer at $\mathrm{pH} 7.5$ was prepared at $25^{\circ} \mathrm{C}$, by mixing $0.68045 \mathrm{~g} \mathrm{KH}_{2} \mathrm{PO}_{4} \cdot 3 \mathrm{H}_{2} \mathrm{O}$ (Sigma, St. Louis, USA) and $4.352 \mathrm{~g}$ of $\mathrm{K}_{2} \mathrm{HPO}_{4} \cdot 3 \mathrm{H}_{2} \mathrm{O}$ (Sigma) in $500 \mathrm{~mL}$ deionized water. For control sample (allopurinol), $2.9 \mathrm{~mL}$ potassium phosphate buffer at $\mathrm{pH} 7.5$ and $0.1 \mathrm{~mL}$ sample were inserted. Meanwhile, for negative control, 2.7 $\mathrm{mL}$ of potassium phosphate buffer $\mathrm{pH} 7.5,0.1 \mathrm{~mL}$ xanthine and $0.1 \mathrm{~mL}$ xanthine oxidase were inserted. As for the samples, $2.6 \mathrm{~mL}$ potassium phosphate buffer at $\mathrm{pH} 7.5,0.1$ $\mathrm{mL}$ xanthine, $0.1 \mathrm{~mL}$ xanthine oxidase and $0.1 \mathrm{~mL}$ sample were inserted. All solutions were inserted into cuvettes and incubated for 10 minutes. Then, $0.1 \mathrm{~mL} \mathrm{HCl}$ was added to stop enzyme reaction. The absorbance measurement was performed using a spectrophotometer at a wavelength of $290 \mathrm{~nm}$.

\section{Preparation of Extract}

Initially, the leaves of $P$. pellucida, A. indica and $M$. charantia, obtained in Makassar, were cleaned, washed with water, and cut into small pieces. The herbs were dried and placed in an open space with good circulation without direct sunlight exposure. The dried herbs were then extracted by maceration method. Briefly, the dried herbs were soaked in $96 \%$ ethanol for 24 hours, filtered and re-soaked in $96 \%$ ethanol so that the extraction were perfectly performed. Solvent containing herbs extract was evaporated in a rotary evaporator to obtain a thick extract.

\section{in vitro Xanthine Oxidase Inhibition Test}

Inhibition test of P. pellucida, A. indica and M. charantia ethanol extracts was performed at the optimum condition according to the Sigma product sheet. The optimum condition was indicated as 10 minutes incubation time at $25^{\circ} \mathrm{C}, \mathrm{pH} 7.5,290 \mathrm{~nm}$ wavelength, 0.1 unit $/ \mathrm{mL}$ xanthine 
and $0.15 \mathrm{mM}$ xanthine. Total of $2.6 \mathrm{~mL}$ phosphate buffer was put in a test tube, followed by $0.1 \mathrm{~mL}$ extract. Then $0.1 \mathrm{~mL}$ of $0.15 \mathrm{mM}$ xanthine and $0.1 \mathrm{~mL}$ of 0.1 unit $/ \mathrm{mL}$ xanthine oxidase was added to the mixture and incubated at $25^{\circ} \mathrm{C}$ for 10 minutes. After the incubation, the mixture was immediately added with $0.1 \mathrm{~mL}$ of $1 \mathrm{M} \mathrm{HCl}$ to stop the reaction.

The mixture was measured using UV absorption at a wavelength of $290 \mathrm{~nm}$ to measure unreacted xanthine in the test sample. Obtained inhibition test result was compared to allopurinol result. Pharmaceutical Chemistry Laboratory, Hasanuddin University.

\section{Results}

Table 1 shows xanthine oxidase inhibitory activity results of P. pellucida, A. indica, M. charantia ethanol extracts and allopurinol (as positive control). Concentration, log concentration, inhibition percentage, probit and inhibitory concentration (IC) $)_{50}$ value of each extract and the positive control are shown. $\mathrm{IC}_{50}$ values from each extract were obtained to determine the effect of enzyme xanthine oxidase inhibitory activity. $\mathrm{IC}_{50}$ values were 19.5 $\mu \mathrm{g} / \mathrm{mL}, 77.6 \mu \mathrm{g} / \mathrm{mL}, \quad 17.8 \mu \mathrm{g} / \mathrm{mL}$ and $1.9 \mu \mathrm{g} / \mathrm{mL}$ for P. pellucida, A. indica, M.charantia and allopurinol, respectively.

\section{Discussion}

Plants used in this research were $P$. pellucida, A. indica and $M$. charantia. The plants were extracted by maceration method. Maceration process was done by soaking the sample in a container using extraction liquid of $96 \%$ ethanol for $3 \times 24$ hours with occasional stirring, then filtered. During the soaking, extraction liquid would penetrate the cell wall and enter the cell. Maceration method was chosen to avoid damage of chemical constituents due to the heat treatment, therefore good and selective extract can be obtained.

The primary data of xanthine oxidase inhibition assay results was obtained from the treatment group and a control group. Data were analyzed to determine the percentage of inhibition values, followed by linear regression statistical test and the determination of the inhibitory activity of enzyme xanthine oxidase samples to determine the $\mathrm{IC}_{50}$ value.

Purine bases converted into hypoxanthine by xanthine oxidase are converted into xanthine and uric acid. Uric acid is formed and then discharged through urine, gastrointestinal tract and partially backfilled in tissue in the form of monosodium uric (MSU) crystals, which over time will accumulate and form microtophy. While the inflammatory process that occurs due to the deposition of uric acid crystals in the tissues around the joints, gout is also a term used for a group of metabolic disorders characterized by an increased concentration of uric acid, or also called hyperuricemia.

Enzymes can not work without the substrate, so does enzyme xanthine oxidase that will only work on an appropriate substrate, which is xanthine.

Xanthine oxidase catalyzes xanthine by addition of distilled water and oxygen into uric acid and hydrogen peroxide. Hydrogen peroxide has the ability to diffuse into and penetrate the cell membrane that can cause damage to cells located far from where hydrogen peroxide was formed.

Measurement of xanthine oxidase inhibitory activity was performed according to the Bergmeyer "Method in Enzymology". The samples were measured using spectrophotometer based on the decrease in absorption at $290 \mathrm{~nm}$. Measurement of the activity of xanthine oxidase was done at $\mathrm{pH} 7.5$, because if the atmosphere is too acidic or alkaline, it can cause loss of xanthine oxidase activity.

In vitro testing was conducted to observe the activity of the enzyme xanthine oxidase on the formation of urate crystals. A decrease in the activity of xanthine oxidase in the ethanol extract of $P$. pellucida, A. indica and $M$. charantia will reduce or prevent the formation of urate crystal and hydrogen peroxide. This test was done to determine the extent of the effects that have been caused by the extracts.

Testing $\mathrm{IC}_{50}$ previously used to extract samples contained some activity, P. pellucida extracts showed antioxidant activity (15), inhibitory effects on three cancer cell lines and has a weak suppressor activity in HL-60 cells (16). The methanol extract of $A$. indica, showed anticancer activity against cell-NCIH187 small lung cancer, showed 
Table 1. Determination of inhibition percentage and $\mathrm{IC}_{50^{\circ}}$

\begin{tabular}{|c|c|c|c|c|c|}
\hline Sample & $\begin{array}{c}\text { Concentration } \\
(\mathrm{ppm})\end{array}$ & Log Concentration & $\begin{array}{c}\text { Inhibition } \\
\text { Percentage (\%) }\end{array}$ & Probit & $\mathrm{IC}_{50}(\mu \mathrm{g} / \mathrm{ml})$ \\
\hline \multirow{5}{*}{ P. pellucida } & 200 & 2.3 & 21.01 & 4.19 & \multirow{5}{*}{19.5} \\
\hline & 100 & 2.0 & 35.53 & 4.62 & \\
\hline & 50 & 1.7 & 43.86 & 4.84 & \\
\hline & 25 & 1.4 & 48.61 & 4.96 & \\
\hline & 12.5 & 1.1 & 50.44 & 5.01 & \\
\hline \multirow{6}{*}{ A. indica } & 200 & 2.3 & 60.75 & 5.27 & \multirow{6}{*}{77.6} \\
\hline & 100 & 2.0 & 50.52 & 5.01 & \\
\hline & 50 & 1.7 & 46.76 & 4.91 & \\
\hline & 25 & 1.4 & 40.86 & 4.77 & \\
\hline & 12.5 & 1.1 & 29.31 & 4.46 & \\
\hline & 6.25 & 0.8 & 7.03 & 3.52 & \\
\hline \multirow{5}{*}{ M. charantia } & 100 & 2.0 & 23.99 & 4.29 & \multirow{5}{*}{17.8} \\
\hline & 50 & 1.7 & 42.44 & 4.81 & \\
\hline & 25 & 1.4 & 47.32 & 4.93 & \\
\hline & 12.5 & 1.1 & 52.58 & 5.07 & \\
\hline & 6.25 & 0.8 & 63.56 & 5.35 & \\
\hline \multirow{6}{*}{ Allopurinol } & 5 & 0.7 & 39.55 & 4.74 & \multirow{6}{*}{1.99} \\
\hline & 2.5 & 0.4 & 45.04 & 4.87 & \\
\hline & 1.25 & 0.1 & 51.75 & 5.04 & \\
\hline & 0.625 & -0.2 & 67.98 & 5.47 & \\
\hline & 0.3125 & -0.5 & 77.28 & 5.75 & \\
\hline & 0.15625 & -0.8 & 84.72 & 6.03 & \\
\hline
\end{tabular}


significant anticancer activity against HT-29 colon cancer cells (17), and the test protein denaturation, $37 \mu \mathrm{g} / \mathrm{mL}$ in action proteinase inhibitory and $18 \mu \mathrm{g} / \mathrm{mL}$ for antihyaluronidase activity (18). As well as the methanol extract of $M$. charantia, dose-dependent inhibit the activity of sucrase most powerful of the intestinal mucosa (19), and has disaccharidase-inhibitory activity on the improvement of blood glucose and serum (20).

Each extract was tested in the same concentration, which was $60 \mathrm{mg}$. After determining the concentration, measurement of absorbance obtained from each concentration is the value to be incorporated into the linear regression equation to obtain $\mathrm{IC}_{50}$ value.

The information of $\mathrm{IC}_{50}$ value in this research is aimed to determine the effect and comparison enzyme xanthine oxidase inhibitory activity of the test sample. It was obtained ethanol extract of $P$. pellucida $\quad \mathrm{IC}_{50}=19.5 \mu \mathrm{g} /$ $\mathrm{mL}$, the ethanol extract of $A$. indica $\mathrm{IC}_{50}=77.6 \mu \mathrm{g} / \mathrm{mL}$, the ethanol extract of M.charantia $\mathrm{IC}_{50}=17.8 \mu \mathrm{g} / \mathrm{mL}$, allopurinol (positive control) $\mathrm{IC}_{50}=1.99 \mu \mathrm{g} / \mathrm{mL}$ and the negative controls (combination of enzyme and substrate) has absorbance value of $0,75026 . \mathrm{IC}_{50}$ value was inversely related to the inhibition of xanthine oxidase activity, the smaller the $\mathrm{IC}_{50}$ value, the greater the inhibition activity of xanthine oxidase (Table 1).

Allopurinol was used as a positive control to determine differences of concentration and absorption produced by extracts and allopurinol. From the test sample, it is known that extract of $M$. charantia provides inhibitory effect on the formation of MSU crystals.

\section{Conclusion}

From this study, it can be concluded that ethanol extract of the P. pellucida, A. indica and M. charantia influence the inhibition of MSU crystals formation. It was found that there is a xanthine oxidase inhibitory activity of the samples tested.

The smaller the $\mathrm{IC}_{50}$ value means the greater the inhibition of xanthine oxidase activity of that samples. $\mathrm{IC}_{50}$ values for extracts of $M$. charantia, P. pellucida and A. indica were $17.8 \mathrm{mg} / \mathrm{mL}, 19.5 \mathrm{mg} / \mathrm{mL}$ and $77.6 \mathrm{mg} / \mathrm{mL}$, respectively.

\section{References}

1. Tjay TH, Rahardja K. Obat-Obat Penting: Khasiat, Penggunaan dan Efek-Efek Sampingnya. 5th Ed. Jakarta: PT. Elex Media Komputindo Kelompok Gramedia; 2002.

2. Schunack W, Mayer K., Haake M. Senyawa Obat [translation by Wattimena JR, Soebita S]. Yogyakarta: Gadjah Mada University Press; 1993.

3. Mutschler E. Dinamika Obat: Buku Ajar Farmakologi dan Toksikologi [translation by Widiyanto MB, Ranti AS]. 5th Ed. Bandung: ITB Press; 1991.

4. Sacher RA, McPherson RA, Campos JM, Widmann FK. Widmann's Clinical Interpretation of Laboratory Tests. Philadelphia: Davis; 2000.

5. Tamta H, Kalra S, Mukhopadhyay AK. Biochemical characterization of some pyrazolopyrimidine-based inhibitors of xanthine oxidase. Biochemistry. 2006; 71: 49-54.

6. Wortmann RL. Disorders of purine and pyrimidine metabolism In: Fauci AS, Braunwald E, Kasper DL. Harrison's Principles of Internal Medicine. 17th ed. New York: McGraw-Hill; 2008. p.2444.

7. Murray R, Rodwell V, Bender D, Botham KM, Weil PA, Kennelly PJ. Metabolism of purine and pyrimidine nucleotides. In: Harper's Illustrated Biochemistry. 26th Ed. New York: McGraw-Hill Companies; 2003. p.292-301.

8. Luk AJ, Simkin PA. Epidemiology of hyperuricemia and gout. Am J Manag Care. 2005; 11 (Suppl 15): S435-42.

9. World Health Organization. General Guidelines for Methodologies on Research and Evaluation of Taditional Medicine. Geneva: WHO; 2000.

10. Dalimartha S. Atlas Tumbuhan Obat Indonesia Vol. 4. Jakarta: Penebar Swadaya. 2004.

11. Wijayakusuma H. Atasi Asam Urat dan Rematik ala Hembing. Jakarta: Puspa Swara; 2007.

12. Sio SO, Maramba NPC, Sia IC. Acute oral toxicity of the freeze dried aqueous extract of peperomia pellucida (L) H.B.K. (ulasimang bato) in mice. Acta Medica Philippina. 2001; 37: 1-11.

13. Jamilah M. Penentuan Nilai LD50 Ekstrak Air Herba Akar Kucing (Acalypha indica Linn.) dan Pengaruhnya Terhadap Kadar Asam Urat Dalam Darah Tikus Putih Jantan Yang Diinduksi Kalium Oksonat [Essay]. Depok: Universitas Indonesia; 2008.

14. Wu SJ, Ng LT. Antioxidant and free radical scavenging activities of wild bitter melon (Momordica charantia Linn. var. abbreviata Ser.) in Taiwan. LWT. 2008; 41: 323-30.

15. Nirosa MC. Isolation of chemical compounds from methanol extract of Peperomia pellucid [Thesis]. Terengganu: University of Malaysia Terengganu; 2012.

16. Xu S, Li N, Ning MM, Zhou CH, Yang QR, Wang MW. Bioactive compounds from Peperomia pellucida. J Nat Prod. 2006; 69: 247 50 .

17. Hameed SS, Nagendran S, Muthukumar T, Ramalingam S, Palanisamy S. Influence of Acalypha indica in cell proliferation, cell cycle arrest and anticancer activity in HT-29 colon cell lines. Der Pharmacia Lettre. 2015; 7: 40-52. 
18. Jayaprakasam R, Ravi TK. Evaluation of anti arthritic activity of the root extract of Acalypha indica Linn. using in vitro techniques. Int $\mathrm{J}$ Phyto Pharm. 2012; 2: 169-73.

19. Uebanso T, Aria H, Taketani Y, Fukaya M, Yamamoto H, Mizuno A, et al. Extracts of Momordica charantia suppress postprandial hyperglycemia in rats. J Nutr Sci Vitaminol. 2007; 53: 482-8.
20. Oishi Y, Sakamoto T, Udagawa H, Taniguchi H, KobayashiHattori K, Ozawa Y, et al. Inhibition of increases in blood glucose and serum neutral fat by Momordica charantia saponin fraction. Biosci Biotechnol Biochem. 2007; 71: 735-40. 